\begin{tabular}{|c|c|c|c|}
\hline $\begin{array}{l}\text { KULTURA } \\
\text { i }\end{array}$ & $\begin{array}{l}\text { POLSKA } \\
\text { KOMITET } \\
\text { INSTYTU }\end{array}$ & $\begin{array}{l}\text { AKADEMIA NAUK } \\
\text { SOCJOLOGII } \\
\text { T STUDIÓW POLITYCZNYCH }\end{array}$ & $\underline{\text { ISSN 0023-5172 }}$ \\
\hline & 2015, nr 3 & Z „TERENU” DO ARCHIWUM I Z & Z POWROTE \\
\hline
\end{tabular}

EWA ŁUKASZYK

Uniwersytet Warszawski

\title{
MUZEUM KOLONIALNE, POSTKOLONIALNE, TRANSKOLONIALNE JAKO MODEL ŚWIATA \\ PRZYKŁAD PORTUGALSKI, BRYTYJSKI I MALAJSKI
}

Muzeum jest miejscem, w którym „racjonalny system klasyfikacji jest egzorcyzmem dokonanym przez światły rozum nad tym, co tajemnicze, niepowtarzalne, wieloznaczne" - twierdzi Maria Popczyk (2011, s. 84). Ten system klasyfikacyjny ma dostarczyć modelu świata, który jest przekazywany zwiedzającemu w skrótowej i poglądowej formie, wpisanej w wewnętrzną logikę i organizację ekspozycji. Eksponaty, zarówno okazy przyrodnicze, jak i obiekty etnograficzne oraz dzieła sztuki, stanowią „próbki” reprezentujące rozległość i złożoność świata. Skoro są one podporządkowane kategoryzacyjnej logice ekspozycji, to i reprezentowany przez nie świat zostaje symbolicznie uładzony, sprowadzony do czytelnego schematu.

Głównym problemem, który tu podejmuję, są formy budowania obrazu świata za pośrednictwem przestrzeni muzealnej (i jej derywatu — parku tematycznego) oraz ich rola w budowaniu lokalnego konsensu co do miejsca danej społeczności w szerokiej perspektywie globalnej i co do rodzaju powiązań łączących tę społeczność z różnymi punktami i obszarami na świecie. Muzealny model świata $\mathrm{w}$ znaczeniu, jakie zamierzam analizować, jest więc swoistym uzupełnieniem mapy i globusa jako środków konceptualizacji rzeczywistości globalnej na użytek określonej wspólnoty. Pozwala odpowiedzieć nie tylko na „pytania o całość" (czym jest i jaki jest świat), ale i na podstawowe „pytania relacyjne” (gdzie leży „nasze” miejsce w tym świecie, gdzie znajdują się najważniejsze dla nas punkty odniesienia oraz przestrzenie działania). Za pośrednictwem muzealnych narracji lokalne wspólnoty tworzą więc i przekazują 
własne koncepcje globalności - służące na danym etapie, jak się wydaje, ich interesom symbolicznym. Paradoksem jest więc to, że choć można sądzić, iż globalizacja $z$ definicji jest procesem sprowadzającym lokalne porządki symboliczne do jedności czy tożsamości, to w wytworzonych przez nią warunkach daje się zaobserwować wielość konkurujących ze sobą obrazów globalności wielość lokalnych „modelów świata”. Przytoczę tu trzy przykłady, wyrosłe ze złożoności dawnych powiązań kolonialnych: portugalski, brytyjski i malajski. Dostrzeżenie łączących je związków wymaga rezygnacji z eurocentrycznej perspektywy, uznania miejsca takiego jak Malakka za punkt zerowy szerokiego układu odniesień. Podejmę taką próbę na koniec.

Dawny gabinet osobliwości u progu nowoczesności przekształcił się w publiczne muzeum, stał się zatem czymś na kształt poglądowego mikrokosmosu, miniatury świata, wytworzonej na użytek określonej wspólnoty i zdolnej do jej cementowania dzięki upowszechnieniu i ujednoliceniu jej obrazu rzeczywistości. Rola muzeum jako instrumentu generowania zbiorowej mobilizacji ukształtowała się w epoce kolonialnej. Jak sugeruje Dominic Thomas, wielkie muzea XIX i początku XX wieku zawdzięczały swe istnienie tym samym instancjom, które były odpowiedzialne za ekspansję kolonialną, gdyż służyły im za miejsce „wystawiania na widok publiczny uzyskanych zdobyczy i chwalebnych symboli geopolitycznej władzy” (Thomas 2009, s. 8). Gromadząc „namacalne dowody” potęgi, muzeum tworzyło konsens wokół projektu kolonialnego i tym samym go umacniało.

Konstytuowanie muzeum jako modelu rzeczywistości globalnej jest możliwe dzięki temu, że sztuczny porządek klasyfikacyjny wprowadzony do zbioru trofeów i kuriozów triumfuje nad chaotycznym charakterem świata, jaki owe okazy uobecniają. Ekspozycja stanowi złożony, lecz jednocześnie spójny schemat, wystawiany publicznie $\mathrm{w}$ przemyślanej i celowo ukształtowanej przestrzeni. Członkowie wspólnoty, zachęcani do zwiedzania muzeum, ulegają subtelnej perswazji zmierzającej do przyjęcia przez nich tego spójnego i uogólnionego modelu, co w rezultacie może się przełożyć na spójność ich wyobrażeń o świecie i polepszenie ich współdziałania w ramach rozmaitych projektów realizowanych przez tę zbiorowość. Nic więc dziwnego, że muzea często udostępnia się zwiedzającym za skromną opłatą lub nawet za darmo. Korzyść $z$ budowanej przez nie kohezji obrazu świata uzasadnia ekonomiczny rachunek kosztów związanych $z$ ich organizacją i utrzymaniem.

Obiekty ujęte $\mathrm{w}$ ramy muzealnego uporządkowania przejmują rolę semioforów. Ten termin, zaproponowany przez Krzysztofa Pomiana (2006, s. 100-101), ma oznaczać przedmiot zdolny pełnić funkcję nośnika znaczeń „W danej społeczności", w tym przypadku budującej własną interpretację globalnego światoobrazu. Zostaje więc zaakcentowany lokalny i wspólnotowy wymiar tegoż przedmiotu, uzależniony od zmieniającej się w czasie percepcji zbiorowej. Obiekt wyniesiony do rangi eksponatu zyskuje funkcję semiofora, ale też z czasem może ją tracić, co wymusza cykliczną aktualizację muzealnych ekspozycji. 
Zmieniają się także wspólnotowe narracje, na jakich zasadzają się przesłania wpisane w muzealną przestrzeń. Są one zależne od zbiorowych projektów historycznych i sposobu plasowania się danej wspólnoty wobec świata. Dlatego też muzea mogą odzwierciedlać zarówno projekty imperialne i kolonialne, jak i przemiany w obrazie świata zachodzące po ich upadku. Zasadna zatem wydaje się próba prześledzenia, w jaki sposób muzealna ekspozycja oddaje i upowszechnia wśród członków wspólnoty przewartościowania w obrazie jej relacji ze światem. Zależnie od roli pełnionej w danym czasie w globalnym porządku może to być obraz triumfalny bądź naznaczony stratą, upadkiem, nowymi wyzwaniami, koniecznością adaptacji do nowych realiów czy nowego miejsca. Podejmując analizę przemian od muzeum kolonialnego do postkolonialnego, warto też uwzględnić stadium transkolonialne, w którym wspólnota uwalnia się ostatecznie od zaszłości kolonialnych i zaczyna budować odmienny wzorzec własnych relacji ze światem, nie powielający już „cienia” dawnego imperium i nie zdeterminowany przez dawniej odgrywaną $w$ nim rolę.

Muzeum jako model świata stanowi zatem dynamiczną konstrukcję znaczeniową podlegającą nieustannemu reformułowaniu. $Z$ jednej strony, jak stwierdza Moira G. Simpson (1996, s. 1), kolonialna instytucja muzealna „odzwierciedla zapatrywania i postawy kultur dominujących i gromadzi materialne dowody kolonialnych osiągnięć kultur europejskich, w jakich jest zakorzeniona". $\mathrm{Z}$ drugiej muzeum - jako wpisana w skończoną przestrzeń, schematyczna forma przekazu określonego obrazu świata - odzwierciedla przemiany nieustannie zachodzące $\mathrm{w}$ tym świecie. Nic więc dziwnego, że - jak zauważa Peter Vergo - wystawy muzealne, nawet te określane mianem „stałych”, są efemerycznymi zdarzeniami kultury: „rzadko upływa dekada, nawet w najbardziej konserwatywnych instytucjach, by nie przewieszono, przestawiono, przeniesiono eksponatów albo wręcz całkowicie nie zrekonstruowano "głównych" czy «najważniejszych» galerii” (Vergo 2005, s. 314). Wrażenie niezmienności i ciągłości muzealnych ekspozycji jest więc w dużym stopniu iluzją. Co więcej, muzeum nie tylko odzwierciedla, ale częstokroć wręcz wyprzedza zmieniające się stany świadomości, ma za zadanie aktywnie je kształtować. Jego edukacyjne cele nie sprowadzają się do przekazywania określonych informacji na temat zgromadzonych eksponatów; muzeum ma przede wszystkim wytwarzać określone światoobrazy. W tym znaczeniu przestrzeń muzealna nie tylko streszcza rzeczywistość globalną („świat”), ale także przekazuje odbiorcy jej specyficzną interpretację.

Zakładam zatem, że przyjrzenie się sposobom organizacji ekspozycji muzealnej może stanowić źródło wiedzy o ewolucji całościowych i relacyjnych obrazów świata, jakie zaistniały w różnych kulturach w okresie między zmierzchem epoki kolonialnej a dniem dzisiejszym. Analiza opiera się na trzech przykładach, które zostały tak dobrane, aby reprezentowały różne losy kultur uwikłanych w przedsięwzięcie kolonizacyjne, a następnie jego konsekwencje. Zestawię więc muzea byłych kolonizatorów i byłych kolonizowanych. Różnie zorganizowane 
ekspozycje dostarczą materiału ilustrującego przemiany kulturowe $\mathrm{w}$ trzech miejscach świata: Portugalii, Wielkiej Brytanii i Malezji, a rozważanymi obiektami będą park tematyczny Portugal dos Pequenitos („Portugalia dla najmłodszych") w Coimbrze, Muzeum i Galeria Sztuki Kelvingrove w Glasgow oraz Muzeum Sztuki Muzułmańskiej (IAMM) w Kuala Lumpur. Znaczenia budowane przez każdą z tych placówek zostaną odczytane w kontekście jej fizycznego i kulturowego otoczenia, konkurujących z nią instytucji oraz ewoluujących projektów ideologicznych, w jakie wpisuje się przekazywany przez każdą z nich wizerunek świata. Wybrane obiekty zostaną zinterpretowane jako szczególne świadectwa stanów świadomości zbiorowej, powiązanych z przedsięwzięciem kolonizacyjnym i jego długofalowymi skutkami ponoszonymi zarówno przez kolonizatorów, jak i kolonizowanych. W tym ujęciu akcent pada więc na próby rozwiązania różnorakich problemów wynikających z kolonialnej przeszłości: z jednej strony chodzi o „utratę świata” byłych potęg kolonialnych, których znaczenie i wpływy znacznie zmalały, a z drugiej — o konieczność znalezienia własnej tożsamości i „skonstruowania świata”, przed jaką stają społeczności dawniej poddane wpływom kolonialnym, a następnie zyskujące znaczenie i wpływy w świecie zglobalizowanym. Współczesne kultury pozaeuropejskie nie tylko krytycznie przypatrują się zachodnim ekspozycjom, jak to ukazał Timothy Mitchell w znanej pracy Egipt na wystawie świata (2001), lecz także potrafią konstruować własne muzealne światoobrazy.

\section{COIMBRA: MUZEUM KOLONIALNE}

Druga połowa XIX wieku, era wielkich imperiów, przyniosła wzorzec wystawy światowej, będącej w gruncie rzeczy wystawą kolonialną, nośnikiem obrazu świata podporządkowanego idei dominacji i supremacji cywilizacji zachodniej we wszystkich dziedzinach życia. Niedościgłą, idealną realizacją takiego wydarzenia była wystawa światowa w londyńskim Cristal Palace w 1851 roku. Portugalia, kraj, który najwcześniej rozpoczął swoją ekspansję morską i najwcześniej wypadł z czołówki imperiów kolonialnych pod naporem konkurencji nowych potęg, nigdy nie zdobył się na zrealizowanie ideału dziewiętnastwiecznej wystawy z rozmachem porównywalnym z brytyjskim. Dwudziestowieczny powrót do portugalskiej idei imperialnej za czasów salazarowskich zaowocował pewnymi próbami nawiązania do poetyki „wielkiej wystawy kolonialnej" - przede wszystkim w wielokrotnie analizowanej Wystawie Świata Portugalskiego (Exposição do Mundo Português), która odbyła się w Lizbonie w 1940 roku (zob. Ramos do Ó 1987, s. 177-185; por. Marreiros 2003). Jednakże najbardziej trwała realizacja tego wzorca przybrała postać „zinfantylizowaną" - powstał park tematyczny dla dzieci, Portugal dos Pequenitos w Coimbrze. Został on pomyślany i założony w 1938 roku, a więc u szczytu „idealistycznego nacjonalizmu” propagowanego przez dyktaturę Salazara, i był rozbudowywany aż do lat pięćdziesiątych XX wieku. Być może dzięki temu, 
że obiekt wydawał się błahy i mało znaczący z racji związku z dziecięcą publicznością, przetrwał koniec imperium portugalskiego w 1975 roku. Jeszcze $\mathrm{w}$ połowie lat dziewięćdziesiątych można go było oglądać $\mathrm{w}$ niemal niezmienionym, nie „poprawionym” kształcie ${ }^{1}$. Później park uległ przekształceniom adaptującym go do nowej polityki luzofonii, lansowanej od końca lat dziewięćdziesiątych. Obiekty stanowiące dawną „imperialną mapę” przekształcono w „pawilony krajów posługujących się portugalskim jako językiem oficjalnym”, rzekomo złączonych z Portugalią wspólnotą „mowy i historycznego przeznaczenia". Mimo iż luzofonia już od chwili narodzin wzbudziła głosy protestu jako idea sztuczna, anachroniczna i manipulacyjna (zob. Margarido 2000), do dziś pozostaje ona dominującym światoobrazem portugalskim, stwarzającym przedłużenie mapy świata, na której wciąż jeszcze próbuje się odczytywać zarysy dawnego imperium, nawet jeśli, jak twierdzi Eduardo Lourenço (2004, s. 180), to symboliczne „zamieszkiwanie” przestrzeni imperium, sytuujące się „bardziej na poziomie snu niż rzeczywistości”, jest tylko sposobem zażegnania dojmującego poczucia rozpadu i utraty świata, jakie pociągałoby za sobą ostateczne wyrzeczenie się imperialnego projektu.

Jak stwierdza Benita Parry (2002, s. 67), jednym z nadal aktualnych celów studiów postkolonialnych jest „zrozumienie namacalnej i wyobrażonej obecności imperium wewnątrz codziennej egzystencji imperialnej ojczyzny". Świadectwem tej podwójnej, zarazem uchwyconej w konkrecie i rozbudowanej przez wyobraźnię, obecności może być właśnie kolonialne muzeum dla dzieci, wnoszące do metropolii materialne znaki rzeczywistości imperium, z perspektywy życia codziennego będącego jedynie mglistym i niewyraźnym obrazem. Kontrastuje ono z wielkością czy rozmachem wystawy światowej, jednakże przekazuje nie mniej ciekawy — a jak się okazuje, znacznie bardziej trwały — obraz imperialnego świata.

Pierwotnym zamysłem parku była prezentacja „portugalskiej macierzy”, opierająca się na charakterystycznym dla epoki salazarowskiej rozumieniu tego pojęcia. Oficjalna propaganda lansowała wówczas ideę Portugalii jako kraju „położonego na wielu kontynentach”, stanowiącego nie imperium kolonialne analogiczne do tego, jakie stworzyły inne potęgi europejskie, ale organiczną całość, w której rzekomo miało nie być różnicy między prowincjami położonymi na Półwyspie Iberyjskim a posiadłościami zamorskimi. Park tematyczny oddaje tę wizję, toteż obok miniaturowych obiektów przedstawiających rzeczywistość różnych regionów Portugalii powstało rozległe założenie mające odzwierciedlać poszczególne prowincje zamorskie. Obejmowało ono wystawy o charakterze etnograficznym ulokowane $\mathrm{w}$ pawilonach rozmieszczonych $\mathrm{w}$ ogrodzie botanicznym gromadzącym okazy flory z poszczególnych części portugalskiej wówczas Afryki, Makao, Timoru, a także z posiadłości w Brazylii i Indiach,

1 Odwołuję się do własnych oględzin tego obiektu z 1994 roku. 
które w czasie zakładania parku były już od dawna utracone, ale funkcjonowały w kolonialnej pamięci jako część mentalnej mapy „portugalskiego świata”.

Znacząca jest także lokalizacja parku: nie w Lizbonie, lecz w Coimbrze, mieście symbolizującym ciągłość tradycji kulturowej, będącym między innymi siedzibą uniwersytetu, z którego wyszedł Salazar. To miejsce miało stanowić niejako „prawdziwe serce” Portugalii, bardziej znaczące od samej stolicy. Położona daleko od kolonialnych portów, zachowująca średniowieczny klimat Coimbra symbolizuje zrąb narodu, jego intelektualne tradycje i rdzenne wartości, toteż taka lokalizacja miała wiązać ukazaną w parku tematycznym wizję imperium z najstarszym „korzeniem” tożsamości portugalskiej. Zarazem jeśli ten dziecięcy park miałby być kompletnym „obrazem świata”, to rzucającą się w oczy cechą jest brak takich odniesień, jak „słynne miejsca” w Europie. Próżno tu szukać miniaturowej Wenecji czy atrapy wieży Eiffla. Park ilustruje bowiem stan świadomości, w którym Portugalczycy niejako odwracali się plecami od kontekstu europejskiego, wybierając życie we własnym układzie odniesienia, wyznaczanym przez powiązania kolonialne.

Charakterystyczną cechą koncepcji wystawienniczej zrealizowanej w Portugal dos Pequenitos jest też swoisty „zwrot sensualistyczny”. Miniaturowe budowle zawierały nie tylko artefakty ludów zamieszkujących byłe imperium czy okazy zoologiczne ilustrujące jego świat przyrodniczy, lecz również bogatą ekspozycję „materiałową”, pozwalającą poznać zmysłowo kolonialne substancje: ziarno kawowe, proso, sizal. Imperium miało stać się „namacalną rzeczywistością" w znaczeniu jak najbardziej dosłownym. Podczas moich oględzin tego obiektu w 1994 roku wizja oferowana dziecięcym oczom w Portugal dos Pequenitos była już obrazem całkowicie anachronicznym, reprezentacją świata, który przestał istnieć wraz z dekolonizacją po Rewolucji Goździków i który nie został jeszcze wskrzeszony wraz z nową polityką luzofonii, wyłaniającą się dopiero pod koniec dekady. Stanowił rodzaj przestrzennego schematu pamięci, konserwującego nieistniejące imperium dzięki swoistej logice apelujących do zmysłowego rozpoznania „próbek”.

W latach dziewięćdziesiątych to „muzeum kolonialnych substancji” stało się także anachroniczne $\mathrm{w}$ konfrontacji $\mathrm{z}$ innymi przedsięwzięciami mającymi na celu kształtowanie portugalskiej pamięci. Odzwierciedlało „imperium realne”, które tymczasem przestało istnieć. Wkrótce utraciło więc znaczenie na rzecz placówek nowego typu, utrwalających już tylko coraz bardziej abstrakcyjną pamięć o imperium. Wyrazem nowej koncepcji była na przykład zainicjowana w tym samym okresie, a więc w latach dziewięćdziesiątych ubiegłego stulecia, działalność Komisji na rzecz Upamiętniania Odkryć Portugalskich, z siedzibą w lizbońskiej Casa dos Bicos ${ }^{2}$, gdzie główny nacisk kładziono na

2 Obecnie mieści się tam utworzona w 2010 roku Fundacja José Saramago, również celebrująca abstrakcyjny element domniemanej wspólnoty luzofońskiej, a mianowicie język portugalski (za pośrednictwem tworzonej w nim literatury). 
konstrukcję pamięci przez teksty. Prowadzono więc badania, podejmowano inicjatywy edytorskie, a jeśli organizowano ekspozycje, były to zwykle wystawy bez eksponatów, ograniczające się do plansz obrazujących takie czy inne zagadnienie. Wystawiennictwo operujące realnymi, namacalnymi obiektami zeszło na dalszy plan.

O wiele ważniejszą $\mathrm{w}$ portugalskiej świadomości formą „uprzestrzennienia" pamięci była budowa Centrum Kulturalnego w Belém, którą zainicjowano w 1988, a ostatecznie ukończono w 1993 roku. Jest to kosztowna i rozległa budowla, ciężka i przysadzista pod względem architektonicznym, na którą składają się zwarte masy piaskowca. Poszczególnym pomieszczeniom w obrębie kompleksu przypisano nazwy fortec w pierwszym, a zarazem najrozleglejszym imperium morskim, jakie istniało w XVI wieku, mimo iż są to toponimy coraz bardziej nieczytelne dla współczesnego odbiorcy. Można byłoby to uznać za próbę przebudowy bolesnej, wciąż niezaleczonej pamięci o utracie Afryki przez jej zamianę na pamięć mniej bolesną i bardziej chwalebną, powiązaną z dawniejszym, szesnastowiecznym imperium sięgającym Indii. Imperium utracone zostaje zamienione na symboliczną mapę wpisaną w masywne bryły pokryte płytami piaskowca, mogące sugerować substytut utraconych fortec zamorskich. Wydaje się to zarazem swoistą transkrypcją lekkiego, ludycznego świata kolonialnego dzieciństwa z Portugal dos Pequenitos w „dorosłe” formy ciążącej, niezaleczonej straty.

\section{GLASGOW: MUZEUM POSTKOLONIALNE}

Portugal dos Pequenitos, jako działający nadal, na przekór historii, wytwór salazarowskiej propagandy, czy Centrum Kulturalne w Belém, dające symboliczną replikę utraconych fortec, są świadectwami podejmowanej przez Portugalczyków próby oporu wobec „utraty świata”. Zupełnie inną postawę w bardzo podobnej sytuacji historycznej ucieleśnia znajdujące się w Glasgow muzeum Kelvingrove. O ile Portugal dos Pequenitos materializuje, jak się wydaje, uporczywe trwanie imperialnego modelu świata, przełożonego aktualnie na kategorie luzofońskiej „wspólnoty losów”, o tyle Kelvingrove jawi się jako swoisty "schemat rozpadu", ukazujący zwiedzającym fragmentację dotychczasowego porządku, dezorganizację kategorii. Prezentowana w nim ekspozycja, w takim kształcie, jaki nadano jej po gruntownej reorganizacji w latach 2003-2006, unaocznia wielkie przewartościowanie, akcentuje nieuchronność gruntownej reorganizacji światoobrazu.

I tym razem lokalizacja analizowanego muzeum nie jest bez znaczenia. W lokalnym wymiarze Glasgow niejako ogniskuje proces „utraty świata”. Dzięki rozwojowi przemysłu metalurgicznego i stoczniowego na przełomie XIX i XX wieku miasto zaczęto określać mianem drugiej po Londynie stolicy Imperium Brytyjskiego. Potęga kolonialna przekładała się więc na momenty największego rozkwitu w miejscowej skali. Sprawia to jednocześnie, że proces 
postkolonialnej renegocjacji tego miasta jest pod wieloma względami trudniejszy niż w innych miejscach Wielkiej Brytanii. Glasgow z początku XX wieku, miasto stoczniowe, gdzie budowano wielkie okręty końca epoki kolonialnej, przypuszczalnie nie powróci już do dawnej świetności.

Odwrotnie niż w Portugalii, gdzie aspiracja wystawy kolonialnej nigdy nie została w pełni zrealizowana, otwarte w 1901 roku muzeum Kelvingrove wyrosło właśnie na gruncie organizowanych w tym miejscu wielkich wystaw międzynarodowych. W swojej pierwotnej postaci ta gigantyczna placówka była dobrym przybliżeniem „muzeum totalnego”, zmierzającego do reprezentacji całej złożoności świata przyrodniczego i ludzkiego w rozległej ekspozycji. W ramach pojedynczego, niezwykle pojemnego obiektu łączyła wystawy naturalistyczne, etnograficzne, historyczne, a także muzeum techniki i muzeum sztuki. Heterogeniczność eksponatów, jak w przytoczonej na wstępie definicji Marii Popczyk, miała być $\mathrm{w}$ tych pierwotnych założeniach podporządkowana schematowi klasyfikacyjnemu, i w rezultacie miała tworzyć obraz świata uładzonego i poddanego nadrzędnej kontroli rozumu. Dzięki temu rozległość muzeum mogła budzić podziw, wywoływać zmęczenie, ale nie przytłaczać.

Tymczasem aktualna koncepcja tego muzeum, w stanie, w jakim zastałam je latem 2012 roku, stanowi celową dekonstrukcję tego pierwotnego systemu porządkowania świata. Miejsce ustabilizowanej klasyfikacji zajęło coś na kształt systematycznej deklasyfikacji, polegającej na świadomym i celowym obalaniu dawnych hierarchii symbolicznych. Na przykład okazy motyli zostały umieszczone w jednej gablocie z pochodzącą z przełomu XIX i XX wieku biżuterią, której twórcy sięgali po naturalistyczne inspiracje; przykłady sztuki afrykańskiej zestawiono $z$ dziełami malarstwa nowoczesnego. Mimo iż zachowano zasadniczy zrąb schematu klasyfikacyjnego, a mianowicie podział na 22 galerie tematyczne, to jednak w ich obrębie podstawowe opozycje dawnego systemu, takie jak okaz przyrodniczy-artefakt, dzikie-cywilizowane, zostały sprowadzone do podobieństwa, równorzędności czy wręcz tożsamości.

Podobnie jak $\mathrm{w}$ Portugal dos Pequenitos, również tym razem mamy do czynienia z muzeum rodzinnym, w którym dziecko jest uprzywilejowanym odbiorcą ekspozycji wzbogaconej o wiele elementów interaktywnych. Pojawiają się także uruchamiane co jakiś czas, przykuwające dziecięcą uwagę mechanizmy, odziedziczone po epoce przemysłowego rozkwitu, będącego niegdyś dumą i wyróżnikiem Glasgow. Jednak wymowa tej postindustrialnej i dekonstrukcjonistycznej ekspozycji bywa nie tylko trudna, ale niekiedy także wysoce niepokojąca. Jednym z centralnych elementów jest maszyna ukazana w cyklicznym, płynnym i harmonijnym, a jednak jałowym ruchu; jest to doskonale logiczna i sprawna całość, która niczego nie wytwarza. Niedawnym uzupełnieniem, zupełnie zmieniającym sens wystawy technicznej gromadzącej maszyny jako urzeczywistnienie nowoczesnego zamierzenia przetwarzania świata, jest „Pożeracz czasu" (Chronophage), instalacja Johna Taylora z 2008 roku, mająca postać wielkiego mechanizmu zegarowego, po którym pełznie mechaniczny owad gi- 
gantycznych rozmiarów. Obraz świata prezentowany zwiedzającemu jest więc daleki od prostoty i czytelności. Przeciwnie, jest to obraz, którego główną cechą jest złożoność, współistnienie znaczeń, symultaniczność wielokierunkowych oddziaływań. Zasadniczym rysem konstruowanego światoobrazu jest więc wdrażanie do postrzegania rzeczywistości pozbawionej kluczy czy jednolitej interpretacji, przygotowanie do życia w świecie ulegającym fragmentacji i transformacji. Jakkolwiek ambitnie miałoby to zabrzmieć, ekspozycja uczy przekraczania nowoczesności.

Co ciekawe, muzeum w Glasgow wyraźnie różni się od placówki pod wieloma względami siostrzanej, za jaką można by uznać Scottish Museum w Edynburgu, nadal zachowujące podstawowy porządek klasyfikacyjny dawnego „muzeum scjentystycznego". Mogłoby to sugerować, że Edynburg, miasto odległe o zalewie kilkadziesiąt kilometrów od Glasgow, jest miejscem bardzo odmiennym $z$ tego względu, że znalazło nową, definiującą je rolę jako ośrodek administracyjny i ważne miasto kultury (m.in. jako znaczący ośrodek teatralny na mapie Europy). Nie doszło więc do tak głębokiej jak w Glasgow „utraty świata", zagubienia poczucia własnego miejsca i znaczenia. Reorganizacja muzeum w Glasgow mogłaby być widziana jako swoista kapitulacja. Możliwa jest jednak odwrotna interpretacja: wychodząc naprzeciw zmieniającemu się światu, miasto próbuje odzyskać swoją awangardową rolę. Przebudowa Kelvingrove wpisuje się $\mathrm{W}$ proces renegocjacji przestrzeni muzealnych „pod naporem pamięci”, który stał się istotnym postulatem począwszy od lat dziewięćdziesiątych XX wieku, gdy zaczęto kształtować nowy paradygmat muzealniczy (zob. Simpson 1996; Thomas 2009). Chodzi o „napór pamięci” heterogenicznej, wymuszającej przewartościowanie jednorodnych światoobrazów, jakie dominowały w epoce kolonialnej. Muzeum nie może pozostać „odzwierciedleniem zapatrywań i postaw" kultury dominującej, lecz musi wpisać się w proces fragmentacji i reorganizacji postkolonialnego społeczeństwa.

\section{KUALA LUMPUR: MUZEUM TRANSKOLONIALNE}

W 1957 roku, gdy Malezja uzyskała niezależność od Wielkiej Brytanii, miała za sobą długą i zróżnicowaną historię kolonialną. Na początku XVI wieku strategicznie położona Malakka została zajęta przez Portugalczyków, który wznieśli tam jedną z owych twierdz, o których pamięć pokutuje w Portugal dos Pequenitos i Centrum Kulturalnym w Belém. W XVII wieku przewagę uzyskali Holendrzy, a następnie Anglicy. Zróżnicowanie europejskich wpływów nakłada się na wielość etniczną i religijną przybyszów z różnych części Azji. Pierwszym zadaniem $\mathrm{w}$ warunkach postkolonialnych było więc stworzenie poczucia wspólnotowości, co początkowo próbowano zrealizować sięgając po wzorce zapożyczone od ostatniego kolonizatora, a więc tworząc muzeum narodowe przypominające podobne placówki w Europie. W założonym w 1963 roku Muzium Negara poszczególne części ekspozycji miały w założeniu odsyłać do 
składników tożsamości narodowej: wspólnej historii, ojczystej przyrody oraz roli ludu, który - wedle Herderowskiej inspiracji - miał stanowić zrąb narodowości. Ekspozycja przedstawia zarówno pamięć o dawnej niezależności, jak i złożoną pamięć kolonialną. Portugalska forteca La Formosa została odtworzona we wnętrzu muzealnym w skali 1:1; nie brak też pamiątek po morskiej potędze Europejczyków w postaci szczątków wydobytych z wraków. Reprezentowana jest także historia kolonialnego wyzysku gospodarczego, z jej najbardziej typowym dla Malezji rysem, jakim było, obok eksploatacji kauczuku, uciążliwe i pracochłonne pozyskiwanie cyny na bagnach. Muzeum postkolonialne nie jest jednak nastawione na rozrachunek. Kolonizacja jest rzutowana na tło „długiego trwania”, obrazowanego przez eksponaty o charakterze archeologicznym i liczne pamiątki świetności sułtanatów malajskich. Przeszłość kolonialna zostaje $\mathrm{w}$ ten sposób zredukowana do jednego $\mathrm{z}$ wielu epizodów historii. Nie dominuje w całokształcie pamięci i nie determinuje jej. Przesłanie tej placówki nie zmierzało do podsycania nienawiści wobec byłego kolonizatora, lecz raczej do uformowania, poprzez pamięć historyczną, wyobrażonej tożsamości malajskiej, w której dominującym rysem miała być wspólnota losów historycznych. Elementy religijne, stanowiące wyznacznik różnorodności, ale i podziałów malajskiego społeczeństwa, były usuwane w cień. Muzeum zacierało kultowe przeznaczenie eksponatów i redukowało je do statusu pamiątek przeszłości. Przestawały nieść żywą, aktualną treść kulturową, obciążoną groźbą podziałów, a stawały się elementami zakonserwowanego i zneutralizowanego dziedzictwa zaprzeszłego.

Postkolonialna koncepcja muzeum nie oddawała złożonej tożsamości społeczeństwa kupców przybyłych z Indii, Chin, Persji i Arabii, współistniejących $\mathrm{z}$ „rdzenną" ludnością, której korzenie na tym obszarze sięgały także zaledwie XIV wieku i która zachowała pamięć o swoim sumatrzańskim pochodzeniu. Jednakże muzeum narodowe okazało się koncepcją nieadekwatną do malajskich aspiracji przede wszystkim dlatego, że skupiało się na swoistym bytowaniu lokalnym, opartym na akcentowanym związku z ziemią; nie tworzyło zaś rozleglejszego obrazu malajskich powiązań ze światem. Tę nową funkcję miało pełnić muzeum transkolonialne, całkowicie oderwane od pamięci kolonialnej, wzorców odziedziczonych po kolonialnych relacjach kulturowych, a także od postkolonialnej świadomości głoszącej, że po rozpadzie imperium nie pozostaje nic innego, jak istnienie osiadłe, związek z zamieszkiwaną ziemią. Brytyjski protektorat regulował przecież przede wszystkim kształt stosunków zewnętrznych utrzymywanych przez Malajów z resztą świata. Jego kres zmusza do stworzenia nowej mapy, w której te stosunki będą nie tylko nawiązywane samodzielnie, bez zewnętrznego patronatu, ale też stworzą powiązania nie wynikające $z$ zarysów minionego imperium.

Co ciekawe, muzeum transkolonialne zbliża się w paradoksalny sposób do sposobu funkcjonowania muzeum kolonialnego. Warto powrócić w tym momencie do przytoczonej na wstępie definicji Moiry G. Simpson, która stwierdza, 
że kolonialna placówka muzealnicza „odzwierciedla zapatrywania i postawy kultur dominujących". Nowa koncepcja opiera się przede wszystkim na identyfikacji kultury dominującej, co w malajskim kontekście nie jest bynajmniej oczywistością. Podobnie jak w przypadku Glasgow, również w Kuala Lumpur mamy do czynienia ze społecznością, która zmaga się z własną heterogenicznością. Jednak sytuacja jest poniekąd odwrotna. Społeczeństwo brytyjskie dekonstruuje obraz i pojęcie kultury dominującej, tu zaś dominacja symboliczna jednego $z$ elementów mieszanki etnicznej i religijnej dopiero się wyłania i szuka sposobów utwierdzenia. Tak więc to, co w Glasgow było stanem, od którego się odchodzi, tutaj rysuje się jako pożądany punkt dojścia. W ten sposób w 1998 roku, w bezpośrednim sąsiedztwie dawnego muzeum narodowego, powstaje muzeum sztuki muzułmańskiej, Islamic Arts Museum Malaysia w nawiązaniu do wielkich muzeów świata zachodniego określane efektownym skrótem IAMM. Mimo iż muzułmanie stanowią niewiele ponad połowę mieszkańców kraju, islam zostaje uznany za ponadetniczny element aglutynacyjny, mogący posłużyć do scementowania zbiorowości. Ma pełnić rolę nadrzędną w stosunku do pozostałych wyznań, moderując relacje różnych grup etnicznych. Ma zarazem stanowić klucz sytuujący Malezję w świecie. To właśnie przesłanie ma przekazywać nowe muzeum.

Ekspozycja akcentuje unifikacyjne znaczenie islamu wyniesionego do roli zwornika, bez którego społeczna kohezja byłaby nie do osiągnięcia. Jednocześnie religia sytuuje Malajów w sieci zewnętrznych relacji, wpisuje w cywilizacyjny, a nawet transkulturowy kontekst. Islam nie tylko spaja wspólnotę na poziomie lokalnym, „lecz zarazem łączy Malajów z ludami innych części świata i z systemem myśli oraz zachowań leżącym poza i ponad jakąkolwiek konkretną kulturą" (Zakaria, Latif 2008, s. 17). Opowiedziana przez muzealną ekspozycję historia rozpoczyna się od ekspansji islamu w Azji, ale wbrew pozorom wyłaniająca się tu narracja nie opowiada po prostu historii religii, lecz raczej używa jej w roli zwornika organizującego przestrzeń i historię obszarów położonych w basenie Oceanu Indyjskiego. W przeciwieństwie do muzeum narodowego malajskie artefakty czy pamiątki miejscowej historii nie są wcale uprzywilejowanymi eksponatami. Jest ich niewiele, dość jednak, by zaznaczyć centralne (w porządku ekspozycji i w wyobrażonej przestrzeni) miejsce Malezji. Eksponaty obcego pochodzenia dominują nie tylko liczbą, ale też materialnym i wizualnym bogactwem. Ich funkcją jest wszakże nakreślenie konturów świata otaczającego Malezję, a sam fakt ich obecności w Kuala Lumpur stanowi namacalny dowód istnienia powiązań tych obszarów z Malezją oraz uzyskanych przez Malajów możliwości ich zdobycia. Podobnie jak w muzeum kolonialnym, gdzie ekspozycja miała unaocznić rozległość wpływów, rozmach przedsięwzięć eksploracyjnych czy wreszcie militarną przewagę pozwalającą na bezkarny rabunek skarbów innych kultur, tak też i tutaj chodzi o wyeksponowanie posiadanych możliwości pozyskiwania cennych obiektów. W ten sposób obszar sięgający od wschodniego wybrzeża Afryki przez Arabię, Persję, Azję Centralną 
i Indie aż do Chin podlega symbolicznemu zawłaszczeniu przez malajską wyobraźnię.

Otóż i transkolonialny wymiar tego muzeum. Tworzy i przekazuje autonomiczną wizję świata, nie powtarzając wzorców ani nie odwołując się do konturów żadnego z dawnych imperiów kolonialnych. Dochodzi tu zarazem, wzorem muzeum kolonialnego, do swoistej formy przemocy symbolicznej, jeśli tym mianem można określić nagięcie i zniekształcenie obrazu świata i zawłaszczenie rozległego obszaru globalnej przestrzeni. Staje się ona swoistym „imperium wyobrażonym”, które nigdy nie było rzeczywistością polityczną, ale zarazem właściwie niewiele się różni od imperium portugalskiego, które taką rzeczywistością już nie jest. Muzeum buduje własną przestrzeń globalną i własną historię, w której - podobnie jak w historii kolonialnej — roi się od przemilczeń i arbitralnych przesunięć akcentów. Zarówno w muzeum kolonialnym, jak i transkolonialnym operacje te są możliwe dzięki mocy tkwiącej w „naoczności” eksponatów - odłamków świata dających się składać w dowolne konfiguracje, ukazujące świat w wykrzywionym zwierciadle.

\section{ZAMIAST PODSUMOWANIA}

W 1994 roku, gdy odwiedziłam po raz pierwszy Portugal dos Pequenitos, trafiłam tam na zaproszenie afrykańskich kolegów z uniwersytetu. Sama ich obecność w Portugalii i w uniwersyteckim kontekście była symptomatyczna. Kilka lat po dekolonizacji i „powrocie z Afryki” Portugalia zaczęła lansować szeroko zakrojony program adresowany do młodzieży z niepodległych teraz krajów, będących jej dawnymi koloniami. W ciągu dekady 1985-1995 przyznano blisko 10000 stypendiów. Można się domyślać, że przyświecały temu nie tylko czysto humanitarne intencje. Była metropolia, wycofując się z dominacji politycznej nad Afryką, pragnęła zachować rząd dusz, co realizowała przez kształcenie przyszłych elit afrykańskich. Studiujący w Coimbrze Afrykańczycy najwyraźniej nie tylko akceptowali, ale i lubili Portugal dos Pequenitos. Postrzegali zawartą w nim reprezentację świata afrykańskiego jako własną, bliską i zasadniczo prawdziwą. Nie identyfikowali jej z pozostałościami propagandy kolonialnej, na której dyskursywne ślady byli skądinąd bardzo wyczuleni. Być może nie potrafili jej rozpoznać $w$ bardziej abstrakcyjnych, symbolicznych aranżacjach przestrzennych, a może ulegali złudzeniu, że „prawda” przedmiotów i artefaktów, odłamków afrykańskiej rzeczywistości, nie podlega przekłamaniom. Nie świadczy to bynajmniej o ich naiwności. Konstruowanie przestrzeni muzealnych i wystawienniczych niesie ze sobą ogromną skuteczność perswazyjną. Język może, jak wiadomo, wyrażać prawdę lub fałsz, zawiera zasadniczy potencjał generowania obrazów fikcyjnych, a co za tym idzie, manipulacji. Przedmiot nieożywiony, zwłaszcza podany, jak to $z$ reguły bywa $\mathrm{w}$ muzeum, w aurze dawności i autentyczności, niesie ze sobą „milczące świadectwo”, niepodważalną, ontologiczną prawdę, z pozoru sytuującą się poza możliwością 
kłamstwa, jaką wnosi język. Dany bez dyskursywnej interpretacji, do bezpośredniego wglądu - taki, jaki po prostu „jest” - ma, jak się wydaje, niezaprzeczalny wymiar dokumentu. Podobną wartość „dowodową” ma fragment chińskiej ceramiki zdobiony muzułmańskimi inskrypcjami. Dostarcza czegoś na kształt „milczącego poświadczenia” — w tym przypadku tezy o głębokiej islamizacji Chin, która oczywiście nigdy nie miała miejsca, choć taką wizję podpowiada malajskie muzeum. Mocą swojej autentyczności - niewątpliwej, lecz pochwyconej $\mathrm{w}$ ramy nowego znaczenia - eksponat muzealny powołuje do istnienia symulakrum rzeczywistości, przydając mu „namacalności”. Uplasowany $\mathrm{w}$ doraźnym modelu świata na miarę aktualnych potrzeb, użycza mu swojej dawności i stwarza złudzenie zakorzenia w „niepamiętnych” dziejach.

Wrażenie nagiego, niezapośredniczonego „bycia” muzealnego eksponatu jest oczywiście iluzją. Przedmiot zdekontekstualizowany i umieszczony w specjalnej, brzemiennej sensem przestrzeni został wbudowany w nową, nasyconą ideologiczną walencją całość. Ta manipulacja przez kontekst, miejsce, sensotwórczą aranżację układów przestrzennych często uchodzi uwadze, a emocjonalna inwestycja w eksponowane obiekty jeszcze bardziej rozmywa percepcje sytuacji. Stąd ogromna skuteczność muzeów w kreowaniu obrazów świata, również tych nie do końca prawdziwych. Nic więc dziwnego, że nie tylko dawne imperia europejskie, ale i nowe potęgi świata zglobalizowanego posługują się tym narzędziem dyskretnej propagandy.

\section{BIBLIOGRAFIA}

Lourenço Eduardo, 2004, A Nau de Ícaro, seguido de Imagem e Miragem da Lusofonia, Gradiva, Lisboa. Margarido Alfredo, 2000, A Lusofonia e os Lusófonos: Novos Mitos Portugueses, Edições Universitárias Lusófonas, Lisboa.

Marreiros Glória Maria, 2003, Da ideologia da Exposição do Mundo Português (1940) ao espírito e ao percurso da nova museologia (museologia social), „Vértice”, nr 111.

Mitchell Timothy, 2001, Egipt na wystawie świata, tłum. Ewa Klekot, Państwowy Instytut Wydawniczy, Warszawa.

Popczyk Maria, 2011, Ekspozycja muzealna a problem zadomowienia, „Anthropos?”, nr 16-17.

Parry Benita, 2002, Directions and Dead Ends in Postcolonial Studies, w: David Theo Goldberg, Ato Quayson (red.), Relocating Postcolonialism, Blackwell Publishers, Oxford.

Pomian Krzysztof, 2006, Historia. Nauka wobec pamięci, Wydawnictwo Uniwersytetu Marii Curie Skłodowskiej, Lublin.

Ramos do Ó Jorge, 1987, Modernidade e tradição. Algumas reflexões em torno da Exposição do Mundo Português, w: António Costa Pinto (red.), O Estado Novo das origens ao fim da autarcia (1926-1959), t. 2, Fragmentos, Lisboa.

Simpson Moira G., 1996, Making Representations: Museums in the Post-Colonial Era, Routledge, London. Thomas Dominic (red.), 2009, Museums in Postcolonial Europe, Routledge, London.

Vergo Peter, 2005, Milczacy obiekt, w: Maria Popczyk (red.), Muzeum sztuki. Antologia, Universitas, Kraków.

Zakaria Ros Mahwati Ahmad, Latif Latifah Abdul, 2008, Malay Manuscripts: An Introduction, IAMM Publications, Kuala Lumpur. 
COLONIAL, POST-COLONIAL, AND TRANS-COLONIAL MUSEUMS AS MODELS OF THE WORLD:

PORTUGUESE, BRITISH, AND MALAYSIAN EXAMPLES

Summary

This article attempts a comparative view of selected museums (in Coimbra, Glasgow, and Kuala Lumpur) in connection with the colonial, post-colonial, and trans-colonial history of two former empires, the British and Portuguese, as well as an area they colonized, Malaysia. The museum as a model of the world reflects successive cultural projects: from building awareness of the empire; through post-colonial changes; to the phase described as trans-colonial, in which the former colony begins to create its own frames of reference in the world and free itself entirely from symbolic dependence on the former colonizer. At each of these stages, exhibition institutions play an important role as a means of recreating and transferring ideas connected with identity, community, and place in the world.

Key words/słowa kluczowe

museum / museum; exhibition / wystawiennictwo; ideology / ideologia; post-colonial studies / studia postkolonialne; trans-colonial studies / studia transkolonialne 